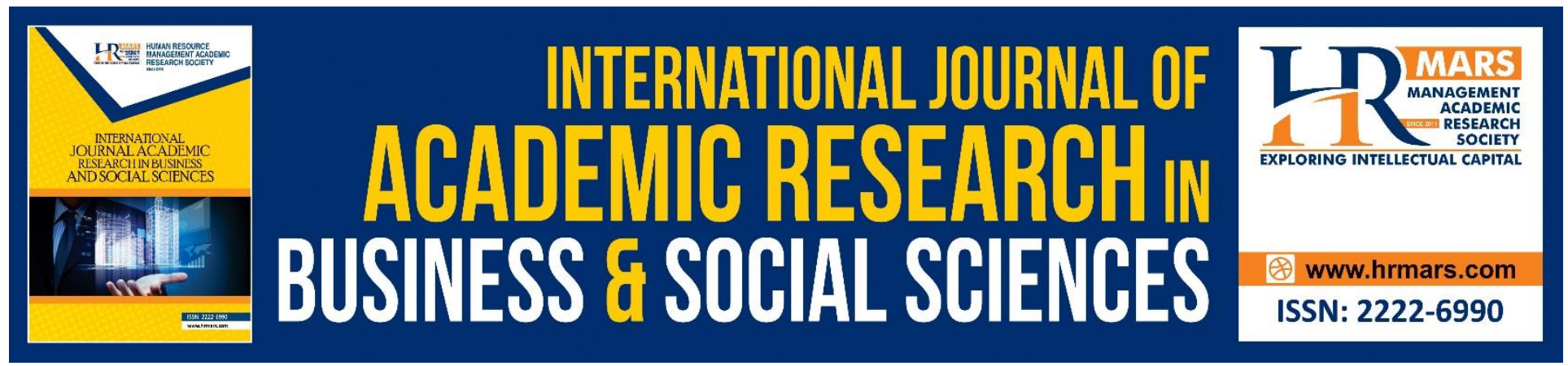

\title{
The Impact of Removing Fuel Subsidies on Domestic Outputs in Malaysia
}

\author{
Loo Sze Ying, Mukaramah Harun
}

To Link this Article: http://dx.doi.org/10.6007/IJARBSS/v9-i3/5732

DOI: $\quad 10.6007 /$ IJARBSS/v9-i3/5732

Received: 05 Feb 2019, Revised: 17 March 2019, Accepted: 30 March 2019

Published Online: 05 April 2019

In-Text Citation: (Ying \& Harun, 2019)

To Cite this Article: Ying, L. S., \& Harun, M. (2019). The Impact of Removing Fuel Subsidies on Domestic Outputs in Malaysia. International Journal of Academic Research in Business and Social Sciences, 9(3), 641-653.

\section{Copyright: (C) 2019 The Author(s)}

Published by Human Resource Management Academic Research Society (www.hrmars.com)

This article is published under the Creative Commons Attribution (CC BY 4.0) license. Anyone may reproduce, distribute, translate and create derivative works of this article (for both commercial and non-commercial purposes), subject to full attribution to the original publication and authors. The full terms of this license may be seen at: http://creativecommons.org/licences/by/4.0/legalcode

Vol. 9, No. 3, 2019, Pg. 641 - 653

Full Terms \& Conditions of access and use can be found at http://hrmars.com/index.php/pages/detail/publication-ethics 


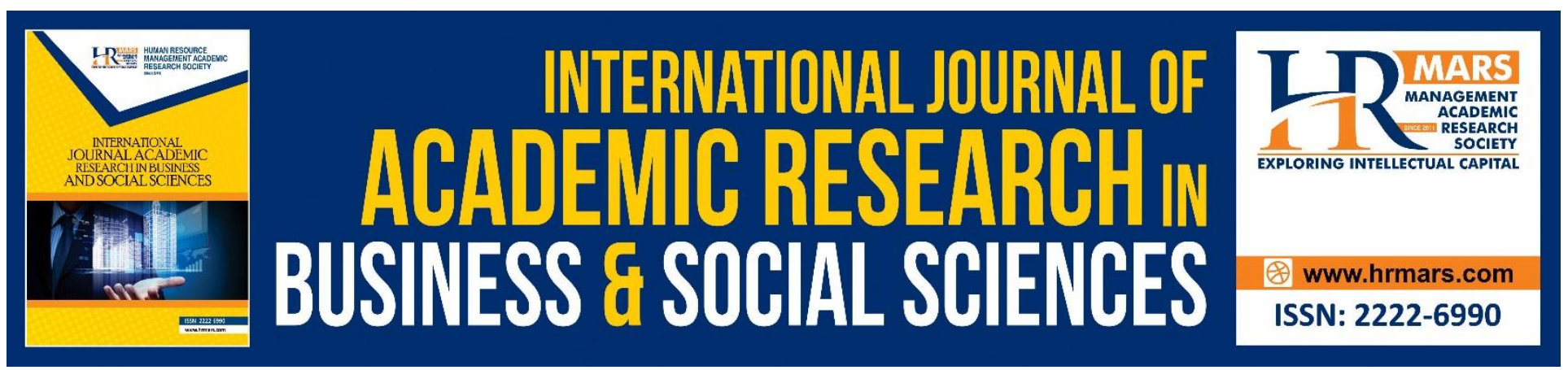

\title{
The Impact of Removing Fuel Subsidies on Domestic Outputs in Malaysia
}

\author{
Loo Sze Ying, Mukaramah Harun
}

School of Economics, Finance and Banking (SEFB), College of Business, Universiti Utara Malaysia

\begin{abstract}
The aim of this study is to examine the impact of ending fuel subsidies on the 19 aggregated sectors in Malaysia. Two alternative complementary policies, including the extra savings' reallocation on agricultural investment and direct cash transfer targeting the poor, were taken into account to mitigate the possible undesirable circumstances under the subsidy removal. To conduct this study, a computable general equilibrium (CGE) model was developed on the basics of the standardized Löfgren CGE model with some appropriate adjustments and assumptions. The empirical results show that the output growth differs considerably across sectors in response to the subsidy removal. On average, domestic outputs decrease. The sectors that consume large amounts of fuel product in their respective production processes, tend to be more vulnerable to this subsidy removal. Nonetheless, an overall improvement in the growth of production is reported by increasing investment on the agricultural sectors compared with the cash transfer. The expansion of agricultural activities demands for more raw materials from other sectors and supply its output as food or as raw material to nonagricultural sectors, bringing an overall economic development. The cash transfer scheme has minimal impact on domestic outputs.
\end{abstract}

Keywords: Fuel Subsidy Removal, Subsidy Saving Reallocation, Agricultural Investment, Cash Transfer, Computable General Equilibrium (CGE) Model, Domestic outputs

\section{Introduction}

Fuel plays an important role in domestic industrial activities, as a core combustible material in running the production process. The presence of fuel subsidies permits domestic producers to gain high benefits of comparative advantage or lower opportunity costs, increasing their competitiveness in the world market, and in return, improve trade balance. However, all manner of benefits that are theoretically possible become different in the reality from what looks good. Fuel subsidies encourage wasteful energy consumption and lead to an inefficient resource allocation (Barany \& Grigonyte, 2015; Sovacool, 2017). The inducement of consuming fuel excessively also leads to environmental damage (IEA, 2013; Anuoti \& Dahl, 2014; Sovacool, 2017). When it comes to sustainable economic growth, the conventional advice for fuel subsidy regime is to get out of the way. Inevitably, enabling 
INTERNATIONAL JOURNAL OF ACADEMIC RESEARCH IN BUSINESS AND SOCIAL SCIENCES

Vol. 9, No. 3, March, 2019, E-ISSN: 2222-6990 @ 2019 HRMARS

access to low fuel prices in the routine operations become inaccessible, affecting firms' competitiveness (Rentschler, Kornejew, \& Bazilian, 2017). Hereafter the firms will resize its operations to curb its loss in future production periods.

Over recent years fuel subsidies have been accused of causing high fiscal deficit and rising national debt primarily in Malaysia, leading to several attempted subsidy reforms on domestic fuel. The bulk of government expenditures went to enormous fuel subsidies, about RM20 billion out of RM40.6 billion of the expenditure was allocated on fuel in 2014 (Malaysian Economic Report, 2014/2015). The situation became far worse with a large economic and fiscal cost when there were extremely high global oil prices. Indeed, the New Economic Model (NEM) gives equal emphasis on environmental sustainability by managing non-renewable resources sustainably through appropriate pricing, regulatory and strategic policies. On 1 December 2014, taking advantage of low global oil price at the time, the managed float system was adopted in determining domestic fuel retail prices where the retail prices were first set based on the monthly average world price of crude oil. The recent situation is all fuel prices are weekly reviewed and determined since the end of March 2017, albeit the prices used to be maintained once at the modest level to stabilize the cost level. Under this fuel subsidy reform, all investment and consumption decisions reveal actual price directions.

Such a change in the fuel subsidy regime from the under pricing to the market-based pricing would place additional burdens on cost of production of the producers, impacting greatly on the value added to domestic economic productivities. The impact comes in both direct and indirect formsproducers would be directly affected when using fuel as a direct production input, and be indirectly affected through the supply-chain channels (Clements, Jung, \& Gupta, 2007; Rentschler, Kornejew, \& Bazilian, 2017). Specifically, energy-intensive sectors that use relatively large amount of fuel product in the production would be greatly affected, from fueling machinery and equipments, transporting inputs to the factories and smoothing the flow of goods and services to remote areas. Generally, the producers tend to raise commodity prices with a reduction in outputs rather than absorb (part of) the high costs to offset the possible loss of earnings, shifting the burden of fuel cost to the end users, which in turn bring out inflationary surge in the market due to the spillover effects.

Considering the government reformed policy of removing the decades-old fuel subsidies, about RM10 billion to RM20 billion of extra fuel savings were to be reinvested into targeted subsidies in the Malaysia Budget 2016 as a complementary policy of removing fuel subsidies. The expanded allocation to rural development, agricultural sector, education and health took placed against the potential unintended impact, together with the introduction of a new 1 Malaysia people's aid scheme (BR1M 2016). Alleviative measures take into consideration as a matter of public benefit. Expanding effective short-term assistance provides the firms more time to invest more structural measures, manage the downside risks of subsidy reform for firms, absorbing the cost shocks temporarily (Rentschler \& Bazilian, 2017; Rentschler, Kornejew, \& Bazilian, 2017). Prioritizing strategic initiatives by properly reallocating the extra savings would turn out short- and long-term multiplier effects (Widodo, et al., 2012). Hence, it helps to increase public acceptance of the reform. 
Ending fuel subsidies pose a major threat to domestic economy through output growth. Thus, this study aims to determine the impact of the subsidy removal on the changes in the outputs across sectors based on a developed computable general equilibrium (CGE) model. Specifically, two alternative complementary policies are incorporated in the removal to identify the extent to how much the potential undesirable impact would minimize. The discussion on the most and less affected sectors impacted from the subsidy changes will be conducted. The next section reviews the output growth links with the changing policy on fuel subsidies. Afterwards the used data and model specification is discussed and is followed by reporting the findings and discussion. Lastly, present the conclusion and recommendations of the study.

\section{Domestic output growth and the changing policy on fuel subsidies}

The government intervention outside the demand and supply mechanisms should be avoided to increase the efficiency of the fiscal policy. Fuel subsidy that does not reflect the true fuel price signals would cause market distortions when it comes to any economic decisions. Low fuel prices do alter production patterns for industries to highly energy-intensive, highly capital-intensive, or less laborintensive (Kosmo, 1987). It induces overinvestment in energy-intensive sectors which could increase the risk of allocating resources and capital from other production sectors where it could be used more productively. In other words, fuel subsidy removal could be mitigated the problem of the resource misallocation.

Needless to say, the subsidy removal will pose a danger to the value-added production due to the heavy use of fuels, driving numerous studies put this subject under the microscope using different types of analysis. Given the limited space of study, this study will focus only related studies. For example, Siddiq, Minor, Grethe, Aguiar, and Walmsley $(2015)^{1}$, by aggregating 21 production sectors from GTAP based on the importance of the Nigerian economy (either for production, consumption or trade), found a decline in the outputs of the transport-communication and electricity sectors, and also other manufacturing sectors as the fuel prices increased. This was because petroleum products contribute 31.7 percent and 23.7 percent of the production cost to transport-communication and electricity respectively. Their study was carried out on the grounds that the subsidy on import petroleum products was removed on January 1, 2012. Also, Widodo, et al. (2012) declared the vulnerability of the chemical and cement, electricity, gas and drinking water sectors to the removal impressed by the heavy subsidized fuel consumption in the Indonesian case. Evidently, the IDR 1billion fuel subsidy removal induced output decreases of about IDR 0.0449 billion in the chemical and cement sectors, and IDR 0.0264 billion in the electricity, gas and drinking water sectors. Definitely, low production level has a large direct impact on the commodity prices concurrent with rising energy costs (Saari, Norhayati \& Ismail, 2013).

${ }^{1}$ Four scenarios were generated in the simulation in Sidiq, et al. (2015): (a) 100\% removal of subsidy on imports; (b) 50\% removal of subsidy on imports; (c) $50 \%$ removal of subsidy on imports and paying subsidy on domestic; and (d) $50 \%$ removal of subsidy on imports and providing transfers to households. 
Paying attention to unintended consequences of the subsidy removal, the fuel subsidy reform should be included a range of carefully designed policy measures. The extra fuel subsidy savings could be injected back into the economic system using autonomous expenditures (Khalid \& Zakariah, 2012). Often, the complete fuel subsidy removal is favorable where the extra savings can be allocated on high-priority measures (Clements et al., 2007; IEA, OPEC, OECD, \& the World Bank, 2010; IMF, 2015), speeding up the successful removal of the subsidy. The evidence in the previous studies revealed that the producers seem to be performing well with the further saving reallocation towards the sectors, enhancing levels of productivity (Maipita, Mohd Dan, Fitrawaty \& Narimo, 2012; Khalid \& Zakariah, 2012; Siddiq, et al., 2015; Rentschler, 2016; Sayed, Sayegh, Saliba \& Stephen, 2015; Akinyemi, et al., 2017). Such a reallocation is quite a contrast to, says, direct cash transfers to the targeted recipients that tend to temporarily protect their consumption level against high prices (IEA, OPEC, OECD, \& the World Bank, 2010; Cooke et al., 2015, El-Katiri \& Fattouch, 2015; IMF, 2017). This cash transfer is one of the most effective and efficient tool in delivery humanitarian aids. Siddiq, et al. (2015) concluded a boom in the domestic production in Nigeria with the government transfer scheme targeting domestic refined oil, but remained modest improvements with the transfer to poor households in the economy.

Increasing concerns on the issue of removing fuel subsidies indicate a need for research on this topic. Studies concerning the impact of the removal on the sectors, and in particular, incorporating further saving reallocations are still insufficient. Moreover, most of the studies in Malaysia were conducted before the implementation of the fuel subsidy reform by counting the fuel price increases such as Saari, Norhayati and Ismail (2013), together with Solaymani, Fatimah and Roza (2013) and Nor Azam, Russayani and Roslan (2014) studied the impact on households. Thus, the aim of this study was to fill in the gap. This study is different where a CGE modeling is employed to capture discrete policy changes within the scope of the study. This study will be beneficial to industries to identify its competitiveness and to the government in formulating more impressed subsidy reform.

\section{Model specification and used data}

The adopted model in this study is a variant form of the Löfgren CGE modeling that was originally developed to present a detailed analysis of food and trade issues in developing countries. Some modifications and assumptions have been made to align with the objectives of the study. The ultimate developed CGE model was used to evaluate the impact of the subsidy removal on the output growth of each aggregated sector in Malaysia. Few specific features for characterizing developing countries, such as the ignorance of transaction costs of commodities and the separation of activities and commodities for production, were also taken into consideration. The study is static and conducted under perfectly competitive markets with only relative price and market clearing condition matter.

The model has 19 industrial sectors of activity and commodity that were aggregated from the 2010 Malaysia IO table. Besides, there are two factor inputs (capital and labor) and 4 main representatives in the economy (households, firms, the government and the rest of world). 
All economic behaviors were fixed coefficients such as the ad valorem tax and subsidy rate, and captured by utility and profit maximization subject to a set of model constraints, according to the nonlinear first-order conditions. Producers maximize profits subject to production technology and cost constraints to decide the combinations between capital, labor and intermediate inputs (including the quantities of imported commodities that used). The aggregated outputs that produced are then allocated to the export and domestic market subject to the constant elasticity of transformation (CET) function. Overall, the mechanism for economic interactions in the model follows closely the Löfgren CGE modeling. Some core equations are discussed as follows.

Production and trade. The model employed a two-level nested production function. The Leontief production function was brought in the top-level production activity, whereas the CES production function was brought in the bottom-level production activity, which includes the intermediate inputs and aggregate value added. The producers in the sectors deal with the activities of transforming inputs of factors and composite goods into outputs. The aggregated marketed output level of the diverse production activities $(\mathrm{QX})$ is given as follows:

$$
Q X_{a, c}=\theta_{a, c} \bullet Q A_{a}
$$

A, $\quad c \quad \in \quad C X$

The supply function for composite goods (spending of domestic outputs and imports) that used as inputs in the production was carried out by the Armington function in equations (2). Then, the aggregated marketed outputs that allocated to domestic market and export in equation (3) is a constant elasticity of transformation (CET) function based on imperfect transformability.

$$
\begin{aligned}
& Q Q_{c}=\alpha_{c}^{q} \bullet\left(\delta_{c}^{q} \bullet Q M_{c}^{-\rho_{c}^{q}}+\left(1-\delta_{c}^{q}\right) \bullet Q D_{c}^{-\rho_{c}^{q}}\right)^{-\frac{1}{\rho_{c}^{q}}} \\
& \text { C } \quad \epsilon \\
& Q X_{C}=\alpha_{c}^{t} \bullet\left(\delta_{c}^{t} \bullet Q E_{c}^{\rho_{c}^{t}}+\left(1-\delta_{c}^{t}\right) \bullet Q D_{c}^{\rho_{c}^{t}}\right)^{\frac{1}{\rho_{c}^{t}}} \\
& \text { C } \quad \epsilon
\end{aligned}
$$

Prices. The price of a single domestically produced commodity is the sum values of domestic sales and exports at producer prices (PX). With the ignorance of marketing costs, the supply price of domestic sales (PE) and the price paid by domestic demanders (PD) are equal.

$$
P X_{c}=\frac{P D_{c} \bullet Q D_{c}+P E_{c} \bullet Q E_{c}}{Q X_{c}}
$$

$\epsilon$

$\mathrm{CX}$

The composite price (PQ) is evaluated in domestic demand prices that limited to the input combination of domestic output and import.

$P Q_{c}=\frac{P D_{c} \bullet Q D_{c}+P M_{c} \cdot Q M_{c}}{\left(1-t q_{c}\right) \bullet Q Q_{c}}$

C

$\epsilon$

$(\mathrm{CD} \cap \mathrm{CM})$

Malaysia is assumed a small country that has no any power in affecting the world prices. Thus, the exogenous determinant of import price (PM) is calculated by using world import prices (pwm), 
exchange rate (EXR) and import tariff $(\mathrm{tm})$. Following this, the price of export is determined by using world export prices (pwe), exchange rate (EXR) and export tax (te). Both world prices and the tariff rate are exogenous in this manner.
$P M_{C}=p w m_{c} \bullet E X R\left(1+t m_{c}\right)$
c
$\epsilon$
$\mathrm{CM}$
$P E_{C}=\left(1-t e_{c}\right) p w e \bullet E X R$
c $\quad \epsilon$
CE

The function of total household consumption expenditure in equation (8) is the net value after the deduction of direct taxes, savings and transfers.

$E H_{h}=\left(1-\sum_{i \in I N S D N G} s h i i_{i, h}\right) \bullet\left(1-M P S_{h}\right) \bullet\left(1-T I N S_{h}\right) \bullet Y I_{h}$

The government. The income sources of the government (YGOV) include a broad range of taxes, factor incomes, and transfers from the rest of the world. The government directs the spending of these incomes (EGOV) to consumption and transfers.

$$
\begin{gathered}
Y G O V=\sum_{h \in H} T I N S_{h} \bullet Y H_{h}+\sum_{e n t \in E N T} T I N S_{\text {ent }} \bullet Y E N T_{e n t}+\sum_{a \in A} t a_{a} \bullet P A_{a} \bullet Q A_{a}+\sum_{f \in F} t f_{f} \bullet Y F_{f} \\
+\sum_{c \in C} t q_{c} \bullet P Q_{c} \bullet Q Q_{c}+t r_{g o v, r o w} \bullet E X R+\sum_{f \in F} Y I F_{g o v, f} \\
+\sum_{c \in C E} t e_{c} \bullet p w e_{c} \bullet Q E_{c} \bullet E X R+\sum_{c \in C M} t m_{c} \bullet p w m_{c} \bullet Q M_{c} \bullet E X R \\
E G O V=\sum_{c \in C} P Q_{c} \bullet Q G O V_{c}+\sum_{i^{\prime} \in I N S D N G} t_{r n s f r_{i, g o v} \bullet C P I}
\end{gathered}
$$

Model closures shaped the equilibrium for the markets of factor, the government, the rest of the world, and saving-investment. By assuming full employment in the factor market, the quantity of each supply factor is fixed and mobile (activity-specific). Besides, the government has flexible fiscal savings and fixed direct taxes in the model. This assumption allows the additional government funds from the subsidy removal to be placed proportionately on further reallocation schemes. Currentaccount balance which is the difference between foreign currency receipt and spending is held constant in the model. To perform a short-run analysis, only exports and imports mattered for the rest of the world with the exchange rate constant. Saving-driven investment is employed to achieve equilibrium in saving-investment market. In other words, capital formation is adjusted flexibly to the saving value that is constant.

The model is built upon various sources of data, including Malaysian input-output table for the base year of 2010, the Household Income Survey (HIS) and Household Expenditure Survey (HES) for year 2009, and national account statistics. These data were mainly obtained from the Department of Statistics, Malaysia (DOSM) to structure the consistent benchmark simulation model with the reference year of 2010. The 19 industrial sectors of activity and commodity were aggregated from the Malaysian input-output table based on the Malaysia Classification of Products by Activities 
(MCPA) 2009. Originally, this 10 table consisted of 124 by 124 production sectors of activity and commodity.

The CGE model is used as an analytical instrument in accessing potential effects of ending fuel subsidies on domestic outputs. This study carried out a simple comparative static model with 3 simulations. All the findings are analyzed and compared with the benchmark year in the next section. Simulation 1 (SIM 01) was fully removing the government fuel subsidies, Simulation 2 (SIM 02) accompanied with the direct transfer scheme targeting the poor and Simulation 3 (SIM 03) paired with the further saving reallocation in the agricultural investment where the total savings amount is proportional to the total amount of the subsidy removal. For the purpose of analysis, all complex mathematical functions were solved using the General Algebraic Modeling System (GAMS) software. To best perform the CGE model, other elasticity values such as elasticity of substitution between capital and labor, and output allocations were derived mainly from Solaymani et al. (2014).

\section{Findings and Discussion}

Table 1 shows the output changes in the 19 aggregated sectors under the fuel subsidy removal. All value changes are measured in real terms, which have been adjusted to the rate of change of the consumer price index (CPI) (inflation-adjusted). The impact of subsidy change on domestic outputs is estimated in terms of percentage changes from the benchmark year in 2010.

In sum, the output growth varies considerably for all simulation analysis. Based on the table 1, only SIM 03 has a positive growth, indicating direct impacts of redirecting extra government funds into agricultural investment (driving growth in some of the co-related sectors). In the SIM 01, the fuel subsidy removal in the economy creates a negative growth with an average reduction of 0.5 percent in the economy. The wood product manufacturing sector shows a remarkable negative growth with a reduced rate of 54 percent due to heavily reliance on fuel product to function conventional technology. The dominance of locally-owned companies (normally small-scale production) in the wood product sector that mostly focusing on primary processing activities and the production of generic products, put it in a very vulnerable position against the subsidy removal.

Nonetheless, the food and beverage manufacturing sector has a significant positive growth with highest increased rate of 48 percent against the subsidy removal. High domestic demand growth as a result of making the switch to basic necessities especially food, in concert with low barriers to entry to meet the rising demands reflects this upward trend (Saleh and Ndubisi, 2006). On the other hand, driving own vehicles for private purposes becomes considerably more expensive when the fuel price is high. Here more people are encouraged to use public transport services. Thus, the transportation sector has a positive growth but the least increased rate of 0.03 percent while the machine, vehicles and others manufacturing sector has a slight contraction in output with only 1.19 reduced rates.

The impact of combining the direct transfer scheme targeting the poor is minimal in SIM 02, which was closely equivalent to the SIM 01 . Such a policy change in the subsidy scheme produces a negative with an average reduction of 0.47 percent. This transfer scheme promotes smooth consumption 
during the adjustment period (Razak, Kamaruddin \& Khalili, 2013). Thus, a biggest chunk of the cash transfers that are reaching the poor segments of the population tend to go to the consumption of necessity items such as foods than keeping it as savings. Excessive domestic demands incur high prices, generating a smaller effect on the output growth.

On the contrary, all subsequent detrimental effects of removing fuel subsidies in SIM 01 are minimized by pairing with the incremental investment in the agricultural sector (SIM 03). The domestic outputs are in the expansion path with an average of about 2 percent increases. The targeted sector which is the agriculture, forestry and fishery sector experiences a growing output against high fuel prices, albeit at a low pace. Besides its output incremental of 0.10 percent, the output increments in the cement, glass and ceramic sector and Iron, steel and metal sector are relatively large at the rates of 95 and 82 percents, respectively. The reason behind this growth is because both of the sectors are being a complementary sector to the other sectors in the economy, strengthening industrial linkages. Materials that produced become essential supplies to agricultural production practices, along with the development of the agriculture, forestry and fishery sector. On the other hand, the agricultural investment discourages the output growth in the chemical product manufacturing sector with the greatest reduced rate of 71 percent. The promotion of sustainable agriculture in the Third National Agricultural Policy (1998-2010) minimizes the use of chemical inputs such as synthetic fertilizers and pesticides to promote environment-friendly agricultural practices. Thus, the incremental investment in the agricultural sector helps to conserve and utilize natural resources sustainably. The cultivation of palm oil which is export-oriented reveals how this works.

Nonetheless, the incremental agricultural investments do not see a parallel improvement in the agrobased manufacturing sectors ${ }^{2}$, the sectors that greatly depend on agricultural raw materials. Specifically, the food processing manufacturing sector has a least output reduction at the rate of 0.18 percent only. Large-scale commercial plantations dominate the cultivation of industrial crops such as oil palm and rubber, yet small-scale farming works for agro-food crops such as paddy, fruits and vegetables. Thus, the quick and sufficient supply of agricultural commodities to agro-based sectors looks uncertain. It has come to the point that the aim of the latest National Agro-food policy (20112020 ) is to reform and transform the agro-food industry to become a more sustainable industry by prioritizing food safety and quality division.

Table 1: The output growth of the sectors (\%)

\begin{tabular}{lccc}
\hline Sectors & SIM 01 & SIM 02 & SIM 03 \\
\hline Agriculture, forestry and fishery & -2.29 & -2.41 & 0.10 \\
Mining, oil and gas & 11.44 & 11.31 & -5.14 \\
Dairy product & 13.26 & 13.07 & -1.63 \\
\hline
\end{tabular}

2 The agro-based manufacturing sectors cover the dairy product, food processing, food and beverage, textile and leather, wood product, rubber product, together with the tobacco, paper products and printings in this study. 
INTERNATIONAL JOURNAL OF ACADEMIC RESEARCH IN BUSINESS AND SOCIAL SCIENCES Vol. 9, No. 3, March, 2019, E-ISSN: 222 2-6990 @ 2019 HRMARS

\begin{tabular}{lccc}
\hline Food processing & 4.78 & 4.71 & -0.18 \\
Food and beverage & 47.91 & 47.20 & -1.23 \\
Textile and leather & -7.56 & -7.44 & -8.52 \\
Wood product & -53.99 & -53.45 & 14.08 \\
Rubber product & -13.72 & -13.67 & -26.25 \\
Tobacco, paper products and & -1.44 & -1.37 & -2.70 \\
printings & -14.63 & -14.35 & 2.01 \\
Oil refinery & 5.99 & 6.01 & -70.92 \\
Chemical product & -11.90 & -11.70 & 94.97 \\
Cement, glass and ceramic & -7.01 & -6.90 & 81.50 \\
Iron, steel and metal & 8.40 & 8.27 & 6.68 \\
Electrical and electronic equipment & -1.19 & -1.17 & 0.37 \\
Machine, vehicles and others & -1.49 & -1.42 & -6.22 \\
Energies & 3.48 & 3.41 & 30.20 \\
Construction & 0.03 & 0.03 & 19.92 \\
Transportation & -5.68 & -5.56 & -0.84 \\
\hline Services & -0.50 & -0.47 & 1.99 \\
\hline AVERAGE VALUES & & & \\
\hline
\end{tabular}

Source: Author's calculation.

\section{Conclusions}

Concerns about the fuel subsidy removal are at the center of policy debates on account of high fiscal deficit and rising national debt. This study seeks to assess the impact of the subsidy removal on sectoral outputs by taking account of transitional measure in Malaysia based on a developed CGE model. From the empirical evidence, the overall impact of ending the fuel subsidy on the sectors is negative. The energy-intensive sectors that heavily dependence on fuel product in the output production would found it greatly affected. They reduce its quantity of output to raising prices in the future, excluding the food manufacturing sectors. Among the two saving reallocations examined in this study- increasing agricultural investment or distributing direct cash transfer targeting the poor, the former is more appropriate in the concerns of future output growth. Overall, these findings are in accordance with findings generated by previous studies that producers benefit greatly with the extra investment in the productive sector against the subsidy removal.

The policy implication of these findings is that the resulting fuel price hike due to the subsidy removal exposes the producers unanticipated high cost burdens. To curb this shock, producers tend to adopt pricing strategy for their goods and services to maximize profits. Thus, it is advisable for the government to place the extra savings gained from the subsidy removal on transitional measure. Any decision on further saving reallocations should be made more prudently to reach the ultimate objectives as expected. Our findings show that the extra direct investments from the government on the agricultural sector may yield promising outcomes. The additional investment allows the agricultural sector to produce more competitive commodities used as intermediate inputs or final 
goods. Moreover, as the output of the agricultural sector expands, the demand for the used inputs from other sectors for production would increase. It would bring great impacts on the economy in return. Despite of this, further evidence is needed to assess the transfer scheme of the direct cash transfer, especially on households.

\section{References}

Akinyemi, O., Alege, P.O., Ajayi, O.O., Adediran, O.S., \& Urhie, E. (2017). A simulation of the removal of fuel subsidy and the performance of the agricultural sector in Nigeria using a dynamic Computable General Equilibrium Approach. Covenant Journal of Business and Social Sciences, 8(1), 60-70.

Anouti, Y.F., \& Dahl, C.A. (2014, Febuary). Rationalizing transport fuel pricing policies and effects on global fuel consumption, emissions, government revenues and welfare (Working Paper No.2014-01). Colorado, US: Colorado School of Mines. Retrieved from http://econbuspapers.mines.edu/working-papers/wp201401.pdf

Barany, A., \& Grigonyte, D. (2015). Measuring fossil fuel subsidies. ECFIN Economic Brief, 40, 1-13. doi:10.2765/85991

Clements, B., Jung, H.S., \& Gupta, S. (2007). Real and distributive effects of petroleum price liberalization: The case of Indonesia. The Developing Economies, XLV-2, 220-237. https://doi.org/10.1111/j.1746-1049.2007.00040.x

Cooke, E.F.A., Hague, S., Tiberti, L., Cockburn, J., \& El Lahga, A.R. (2015). Estimating the impact on poverty of Ghana's fuel subsidy reform and a mitigating response. Journal of Development Effectiveness, $\quad$ 8(1). https://doi.org/10.1080/19439342.2015.1064148 doi:10.1080/19439342.2015.1064148.

International Energy Agency, Organization of the Petroleum Exporting Countries, Organization for Economic Co-operation and Development, \& the World Bank. (2010). Analysis of the scope of energy subsidies and suggestions for the G-20 initiative. Prepared for submission to the G-20 Summit Meeting, Toronto, 26-27 June.

International Energy Agency. (2013). Southeast Asia Energy Outlook 2013. Paris: Author.

International Monetary Fund. (2015). Causes and consequences of income inequality: A global perspective (IMF Staff Discussion Note). Washington, DC: Author.

International Monetary Fund. (2017). Subsidy reform and implications for social protection: An analysis of IMF advice on food and fuel subsidies (IEO Background Paper BP/17-01/02). Washington, DC: Author.

Khalid, A. H., \& Zakariah, A. R. (2012). Combodia's electricity sector in the context of regional electricity market integration. In Wu, Y., X. Shi, and F. Kimura (Eds.), Energy market integration in East Asia: Theories, electricity sector and subsidies (ERIA Research Project Report 2011-17). Jakarta: Economic Research Institute for ASEAN and East Asia (ERIA).

Kosmo, M. (1987). Money to burn? The high costs of energy subsidies. Washington, DC: World Resource Institute.

Maipita, I., Mohd Dan, J., Fitrawaty, \& Narimo, S. (2012). The impact of diverting of fuel subsidy to agricultural sector on poverty. CMU Journal of Economics, 16(1), 84-100. 
INTERNATIONAL JOURNAL OF ACADEMIC RESEARCH IN BUSINESS AND SOCIAL SCIENCES

Vol. 9, No. 3, March, 2019, E-ISSN: 222 2-6990 @ 2019 HRMARS

Malaysia's Performance Management and Delivery Unit. (2010). Government transformation programme: The roadmap. Putrajaya: Prime Minister's Department.

Ministry of Agriculture. (2000). Dasar Agromakanan Negara (2011-2020). Putrajaya: Author.

Ministry of Agriculture. (2000). Third National Agricultural Policy (1998-2010), Executive Summary. Putrajaya: Author.

Ministry of Finance. (2015). Economic Report 2014/2015. Putrajaya: Author.

National Economic Advisory Council. (2010). New Economic Model for Malaysia (Part 1). Kuala Lumpur: Author.

Nor Azam, A.R., Russayani, I., \& Roslan, A.H. (2014). Is there a case for fuel subsidy removal in Malaysia? International Journal of Economics, 2(4), 1-13. http://dx.doi.org/10.18533/jefs.v2i03.54

Razak, A.R., Kamaruddin, R., \& Khalili, J.M. (2013, April). Bantuan Rakyat Satu Malaysia (BR1M): Consumption pattern and the relationship between acceptances, perception towards government sincere incentives and political motives. Paper presented at $2^{\text {nd }}$ International Islamic Business, Kuala Lumpur, Malaysia.

Rentschler, J. (2016). Incidence and impact: The regional variation of poverty effects due to fossil fuel subsidy reform. Energy Policy, 96, 491-503. https://doi.org/10.1016/i.enpol.2016.06.025

Rentschler, J., \& Bazilian, M. (2017). Policy monitor- Principles for designing effective fossil fuel subsidy reforms. Review of Environmental Economics and Policy, 11(1): 138-155. https://doi.org/10.1093/reep/rew016

Rentschler, J., Kornejew, M., \& Bazilian, M. (2017). Fossil fuel subsidy reforms and their impacts on firms. Energy Policy, 108, 617-623. https://doi.org/10.1016/i.enpol.2017.06.036

Saari, M. Y., Norhayati, S., \& Ismail, A.R. (2013). Evaluation of impacts of the rise in energy prices on costs of production and living expenses in Malaysia. Malaysian Journal of Economic Studies, 50(1), 1-20.

Saleh, A.S., \& Ndubisi, N.O. (2006). An evaluation of SME development in Malaysia. International Review of Business Research Papers, 2(1), 1-14.

Sayed, L.E., Sayegh, W., Saliba, E., \& Stephen, J. (2015). Fossil fuel subsidies in Lebanon: Fiscal, equity, economic and environmental impacts. Lebanon: United Nations Development Programme (UNDP). Retrieved from http://climatechange.moe.gov.lb/viewfile.aspx?id=218

Siddig, K., Minor, P., Grethe, H., Aguiar, A., \& Walmsley, T. (2015). Impacts on poverty of removing fuel import subsidies in Nigeria (Policy Research Working Paper No. 7376). Washington, DC: World Bank.

Solaymani, S., Kardooni, R., Fatimah, K., Sumiani, Y. (2014). Economic and environmental impacts of energy subsidy reform and oil price shock on the Malaysian transport sector. Trade Behaviour and Society, 2(2). http://doi.org/10.1016/j.tbs.2014.09.001

Solaymani, S.,Fatimah, K., \& Roza, H.Z. (2013). Evaluating the role of subsidy reform in addressing poverty levels in Malaysia: A CGE poverty framework. The Journal of Development Studies, 50(4), 556-569. https://doi.org/10.1080/00220388.2013.841888

Sovacool, B.K. (2017). Reviewing, reforming, and rethinking global energy subsidies: Towards a political economy research agenda. Ecological Economics, 135, 150-163. https://doi.org/10.1016/i.ecolecon.2016.12.009 
Unit Perancang Ekonomi. (2010). Tenth Malaysia Plan 2011-2015. Kuala Lumpur: Percetakan Nasional Berhad.

Widodo, T., Sahadewo, G.A., Setiastuti, S.U., \& Chaerriyah, M. (2012). Impact of fuel subsidy removal on the Indonesian economy. In Wu, Y., X. Shi, and F. Kimura (Eds.), Energy market integration in East Asia: Theories, electricity sector and subsidies (ERIA Research Project Report 2011-17). Jakarta: Economic Research Institute for ASEAN and East Asia (ERIA). 